\title{
A Few Remarks on the Concept of Secularism and the Judgments of the European Court of Human Rights
}

\begin{abstract}
The article is divided into two parts. The first part discusses a certain concept of secularism, where secularism is considered to be composite of three principles: separation of church and state, freedom of religion, and equality. Subsequently, the European Convention on Human Rights is reflected upon with that concept of secularism in mind. While it does not warrant separation of church and state, freedom of religion and equality are enshrined in it. Therefore, the Convention may be considered secularist to an extent. In the second part, three of the European Court of Human Rights landmark cases are analyzed with regard to secularism. While not much can be said about Kokkinakis v. Greece on its own, the comparison with Leyla Şahin v. Turkey and Lautsi v. Italy allows to point out that appearance of secularism (understood as one of its components - the principle of separation) provides the Court with a possibility to defer to the doctrine of the margin of appreciation and draw the focus away from the actual violation of the principles enshrined in the Convention. Finally, it is noted that the only appearance of the concept of secularism as a personal conviction in the Court's judgment is inconclusive.
\end{abstract}

Keywords: secularism, freedom of religion, European Court of Human Rights, European Convention on Human Rights, Lautsi v. Italy,

Leyla Şahin v. Turkey, Kokkinakis v. Greece

1 Tomasz Famulski - PhD student in Faculty of Law and Administration, Jagiellonian University; e-mail: tomasz.famulski@student.uj.edu.pl; ORCID: 0000-0001-8015-4381. 


\section{Kilka uwag na temat pojęcia sekularyzmu oraz orzecznictwa Europejskiego Trybunału Praw Człowieka}

\section{Streszczenie}

Artykuł podzielony jest na dwie części. W pierwszej części rozważane jest pewne pojęcie sekularyzmu, w którym sekularyzm uznaje się za zestawienie trzech zasad: rozdziału Kościoła od państwa, wolności religijnej, oraz równości. Następnie ma miejsce refleksja nad Europejską Konwencją Praw Człowieka z punktu widzenia powyższego pojęcia sekularyzmu. O ile konwencja nie zapewnia rozdziału Kościoła od państwa, chroni ona wolność religijną oraz równość, co pozwala na stwierdzenie, że jest ona do pewnego stopnia sekularystyczna. W drugiej części pod kątem sekularyzmu analizowane są trzy precedensowe sprawy zaistniałe przed Europejskim Trybunałem Praw Człowieka. O ile niewiele powiedzieć można na temat samej w sobie sprawy Kokkinakis przeciwko Grecji, o tyle porównanie ze sprawami Leyla Şahin przeciwko Turcji oraz Lautsi przeciwko Włochom pozwala zauważyć, że pojawienie się sekularyzmu (rozumianego jako jedna z jego składowych - zasada rozdziału) daje Trybunałowi możliwość powzięcia względu na doktrynę marginesu tolerancji i odciągnięcie uwagi od konkretnego naruszenia zasad chronionych przez Konwencję. Końcowo zauważa się, że jedyne wystąpienie w orzecznictwie ETPCz pojęcia sekularyzmu jako osobistego przekonania jest niekonkluzywne.

Słowa kluczowe: sekularyzm, wolność wyznania, Europejski Trybunał Praw Człowieka, Europejska Konwencja Praw Człowieka, Lautsi v. Italy, Leyla Şahin v. Turkey, Kokkinakis v. Greece 


\section{Introduction}

The aim of this article is to analyze a handful of landmark cases of the European Court of Human Rights with regard to secularism. ${ }^{2}$ The article is divided into two parts. The first part concerns the concept of secularism. This part is mostly an attempt at a terminological clarification. The second part refers to relevant judgments of the European Court of Human Rights. Main hypothesis is that secularism has two meanings: it can be understood as (1) a principle followed by a state and as (2) a personal belief protected by Article 9 of the European Convention on Human Rights. The latter understanding has been at least implicitly acknowledged by the Court in one of its rulings, although the Court predominantly recognizes secularism as a state matter.

Secularism is often defined as separation of the state from religious institutions. A state is secular if it follows the principle of secularism. Contracting states of the European Convention on Human Rights often differ greatly in how they follow this principle: some states tend toward strict separation (French laïcité), and other states are far from actual separation (state-supported Church of Denmark). What the contracting states seem to have in common is the fact that in principle they do not impose any religious position (be it a particular religion or atheism) on their citizens. This allows to conclude that state secularism concerns at least two distinct matters: (1) political system of the state and (2) freedom of religion (which should also entail freedom from religion). This division is apparent in the judgments of the European Court of Human Rights.

Secularism can also be understood as a personal belief or a philosophical conviction that a state ought to be secular. Secularists advocate secularism as a whole, but due to the fact that freedom of religion has been achieved in contemporary liberal democracies, they focus on secularism in the "secular political system" sense. Again, this view can be partially reconstructed from the judgments of the European Court of Human Rights.

The article employs the method of analysis of source material (website of National Secular Society) in its first part and analysis of the judgments in ECHR

2 For a more extensive study, see A.K. Kurtul, Secularism and the European Court of Human Rights (https://www.academia.edu/30080790/SECULARISM_AND_THE_EUROPEAN_COURT_OF_ HUMAN_RIGHTS_AN_UNCANNY_RELATIONSHIP). 
landmark cases in its second part. References to subject literature are also present. The main focus of the article is almost solely on the issue of secularism - the definition, its appearances in the judgments etc. Due to limited space the analysis is restricted to a few landmark cases and not the whole of the judiciary activity of the ECHR. Consideration of other related political concepts (e.g. neutrality, pluralism) is not a subject of this analysis.

\section{What is secularism?}

Even a superficial search for a definition of secularism poses problems. The definition of secularism from the Oxford Dictionaries reads: "the principle of separation of the state from religious institutions." ${ }^{3}$ Indeed, the word separation and the notion of separation of church and state are often associated with secularism. However, the Merriam-Webster dictionary defines secularism as "indifference to or rejection or exclusion of religion and religious considerations." ${ }^{\prime 4}$ On one hand, this definition is a broader one; on the other hand, it does not directly mention neither separation nor the state. It suggests that secularism might be something more than just a principle of separation. To make matters worse, a definition of the Polish equivalent (sekularyzm) reads as follows: "lack of correlation and integration between religion and public matters of society; laicity." ${ }^{5}$ These definitions are full of vague terms. Does the separation have to be a complete separation for a state to be secular? How is indifference distinguishable from rejection? Does laicity entail that a member of the clergy cannot be invited to a national celebration? Also, even if secularism was to be considered synonymously with separation of church and state, the latter notion has dozens of differing variants - every secular state adopts its own model of separation.

To define secularism more precisely, a more comprehensive study, extending beyond the limits of a single article, would be required. However, for the purposes of this paper, at least a working definition of secularism is needed. Perhaps it would suffice to adopt results of some detailed philosophical inquiry. All that notwithstanding, this author would like to propose a different approach, and suggest to look for an explanation of secularism among the secularists themselves. Perhaps - if the analogy is not overly far-fetched - to look for a concept of secularism as

3 https://www.lexico.com/en/definition/secularism

4 https://www.merriam-webster.com/dictionary/secularism

5 https://sjp.pl/sekularyzm („,brak współzależności i integracji między religią a publicznymi sprawami społeczeństwa; świeckość"). 
presented by secularists would be something in the spirit of American legal realism: to look for secularism in action, as opposed to secularism in books. After all, it is the supporters of secularism who pursue a certain concept in everyday life, who often participate in court cases, who are active in propagating and defending the notion. It may be well argued that they have the best knowledge of what the contemporary secularism actually is. It will be supposed that the views they present are sincere, i.e. they do not have any hidden agenda.

The website of a British secularist organization, the National Secular Society, contains a page entitled What is Secularism?, which presents the case in the following way:

"The principles of secularism which protect and underpin many of the freedoms we enjoy are:

1. Separation of religious institutions from state institutions and a public sphere where religion may participate, but not dominate.

2. Freedom to practice one's faith or belief without harming others, or to change it or not have one, according to one's own conscience. ${ }^{6}$

3. Equality so that our religious beliefs or lack of them doesn't put any of us at an advantage or a disadvantage." 7

Unsurprisingly, it is clearly visible that the notion of separation of church and state constitutes an important part of secularism. However, the other two principles of secularism are absent from the aforementioned definitions - freedom and equality seem to largely extend the concept of secularism. Moreover, this passage appears to be in conflict with rejection or exclusion of religion: religion may participate in the public sphere, and one is free to practice one's faith or belief. The text puts a lot of emphasis on freedom of religion (which entails freedom from religion) and on equality: "Secularism seeks to ensure and protect freedom of religious belief and practice for all citizens. Secularists want freedoms of thought and conscience to apply equally to all (...). Secularism seeks to defend the absolute freedom of religious and other belief, and protect the right to manifest religious belief insofar as it does not impinge on the rights and freedoms of others. Secularism ensures that the right of individuals to freedom of religion is always balanced by the right to be

6 Perhaps a certain - for lack of a better word - leap of faith is required to accept this principle, as it is at times argued that secularists have a history of hostility toward religious freedom; cf. C. Eberle, T. Cuneo, Religion and Political Theory, [in:] E.N. Zalta (ed.), The Stanford Encyclopedia of Philosophy, Stanford 2017.

$7 \quad$ https://www.secularism.org.uk/what-is-secularism.html 
free from religion (...). [Secularism] upholds equality laws that protect women, LGBT people and minorities from religious discrimination."

It is also pointed out that "Secularism protects free speech and expression." While freedom of speech and freedom of expression are not mentioned alongside separation of religious institutions from state institutions, freedom of religion, and equality, they might be understood as a consequence of these three principles.

The elaboration extensively quoted above unequivocally points toward extending the concept of secularism beyond the mere notion of separation of church and state. There is visible stress on other aspects underlying secularism, i.e. freedom of religion, equality, and on freedom of speech and freedom of expression as well. If one was to concentrate on this particular extension, leaving aside for a moment the problem of separation of church and state, an interesting observation with regard to the European Convention on Human Rights would be possible.

\section{Two faces of secularism and the European Convention on Human Rights}

European Convention on Human Rights does not require its signatory states to be secular; in fact, there is no mention of secularism throughout the Convention and its supplementary Protocols. However, bearing in mind the underlying principles of secularism just presented, it could be argued that the Convention is in fact somewhat secular in spirit. Emphasis has been put on freedom of religion and on equality. Indeed, the Convention includes provisions that concern these principles: Article 9, which is entitled "Freedom of thought, conscience and religion", states that " 1 . Everyone has the right to freedom of thought, conscience and religion; this right includes freedom to change his religion or belief and freedom, either alone or in community with others and in public or private, to manifest his religion or belief, in worship, teaching, practice and observance. 2. Freedom to manifest one's religion or beliefs shall be subject only to such limitations as are prescribed by law and are necessary in a democratic society in the interests of public safety, for the protection of public order, health or morals, or for the protection of the rights and freedoms of others." 10 The text of this provision appears to be in line with the principle of freedom of religion mentioned above.

8 Ibidem.

9 Ibidem.

10 Convention for the Protection of Human Rights and Fundamental Freedoms (European Convention on Human Rights, as amended), Art. 9. 
Equality is enshrined in the Convention as well. Article 14 states that "the enjoyment of the rights and freedoms set forth in this Convention shall be secured without discrimination on any ground such as sex, race, colour, language, religion, political or other opinion, national or social origin, association with a national minority, property, birth or other status." ${ }^{11}$ Discrimination on the grounds of religion is clearly prohibited by this provision. Again, another principle underlying secularism is apparent in the Convention.

Although freedom of speech and freedom of expression are only mentioned in passing on the website of the National Secular Society, it is worth noting that these values are protected by the Convention as well. Article 10 of the Convention states that "everyone has the right to freedom of expression. This right shall include freedom to hold opinions and to receive and impart information and ideas without interference by public authority and regardless of frontiers." 12

What these extensive quotations from the European Convention on Human Rights try to illustrate is the fact that the principles underlying secularism (or at least a version of it to which the National Secular Society adheres) are visibly present in the Convention. However, the principle of separation of church and state is absent from the Convention. This allows to observe that in fact at least some particular form of secularism is enforced by the Convention. This form may be described as largely limited, as the separation of church and state is not included. However, the inclusion of freedom of religion (and freedom from religion), prohibition of discrimination on the grounds of religion (or lack thereof) makes the Convention secular to an extent.

One must bear in mind that the working definition of secularism used in this article does not equate secularism with separation of church and state, but rather treats the issue of separation as an important part of secularism, with other important parts also in existence. Therefore, with regard to the Convention, these components of secularism may be divided into two kinds: (1) separation of church and state and (2) other principles. The latter kind includes freedom of religion etc. and is enshrined in the Convention. It follows that there exists a certain European consensus with regard to these principles - they are widely accepted and adhered to by the signatory states. Conversely, there is no consensus with regard to the principle of separation of church and state. Every state adopts its own version of said principle and these versions differ greatly throughout Europe - from French laïcité (so far-reaching that it is also called hostile separation in legal literature) to a state-supported Church of Denmark (which even performs some bureaucratic functions).

\footnotetext{
11 Ibidem, Art. 14.

12 Ibidem, Art. 10.
} 
The issue of separation is inherently controversial, or at least more controversial than other principles. For instance, in the About section of the website of National Secular Society following remarks are made: "We work in the UK and internationally to challenge religion's disproportionate influence on governments and in public life. We defend freedom and equality as a counterbalance to the powerful religious lobby and religious impulses that can threaten human rights worldwide."13 This passage presupposes that there exists religion's disproportionate influence on governments and in public life. Consequentially, if one accepts this view, it is reasonable for a supporter of secularism to advocate more extensive form of separation of church and state. However, this support in based on the condition that the aforementioned presupposition is believed to be correct. Such a presupposition is not necessary for the support of the principles of freedom of religion, equality, etc.

However, the crucial difference between the issue of separation and the other secular principles is the fact that these other principles are universally enshrined in law. This may be such an obvious fact nowadays that even the secularists themselves seem to forget that it is indeed a success for secularism. Consider the following remark from the already known website: "As the UK has become increasingly majority non-religious many forms of religious privilege have fallen by the wayside e.g. few people now seriously suggest atheists or non-Christians can't serve on juries. But others have continued, mainstream politicians still think accusing all atheists of being immoral is acceptable."14 Banning non-Christians from serving on juries would be an obvious violation of the prohibition of discrimination on the grounds of religion - so obvious that practically no one would consider it seriously in a contemporary democratic state. However, accusations of all atheists being immoral is present in public debate - it would be a question of separation for such arguments not to be present in public life. The passage quoted above may serve as a kind of proof that the distinction made earlier makes sense: even the secularists themselves realize that certain freedom has been achieved in contemporary liberal democracies, and it is the degree of separation that still poses an issue. One might even say that by widespread acceptance of freedom of religion etc. a separation of church and citizen has been achieved. Such a statement emphasizes the fact that separation of church and state is something different - it concerns issues like the presence of religion in public debate, or relations between religion and state institutions. No matter what model of separation a state adopts, its citizens are always able to separate themselves (one might say 'be protected') from religion.

\footnotetext{
13 https://www.secularism.org.uk/about.html

14 https://www.secularism.org.uk/what-is-secularism.html
} 
Apart from the fact that freedom of religion, equality and prohibition of discrimination are widely accepted and enshrined in law, another difference between separation and aforementioned principles exists. While the principles are always enshrined in law, separation may also be a matter of tradition or social customs, and it is not necessary for it to be protected by law. For instance, one may support a view that religious leaders should not participate in celebrations of state holidays - such a state of things would be a consequence of separation of church and state. However, it does not have to be legally warranted, i.e. a legal act prohibiting the presence of religious leaders during said celebrations is not necessary; for a supporter of secularism it may suffice that religious leaders are simply not invited. Conversely, it would not be enough if, for instance, prohibition of discrimination was only habitually obeyed and not legally warranted.

\section{Secularism as a matter of a political system}

European Court of Human Rights has not formulated any elaborate concept of secularism. In light of the considerations presented in the previous section, this does not come as a surprise. The Court decides cases concerning alleged violations of the European Convention of Human Rights, including violations of freedom of religion, equality, and prohibition of discrimination. This would suggest that the Court is supposed to focus on these values, and does not need to trouble itself with the issue of secularism of particular contracting states. In spite of all this, the notion of secularism appears in the Court's judgments, in particular judgments concerning alleged violations of freedom of religion. ${ }^{15}$ All but one of those appearances mention secularism as a principle followed by a contracting state. Only in one instance does the Court refer to secularism as a personal conviction - this unique passage will be discussed in the next section.

Not only does the Court take note of secularism, it seems to be taking note of it in a way that appears to be somewhat inconsequential. This observation is supported by an analysis of three of the Court's landmark cases. Let us consider these cases chronologically. First case, which is perhaps also the first landmark case concerning freedom of religion in general, is Kokkinakis v. Greece ${ }^{16}$. In this case, the

15 For a detailed account of ECHR complicated behavior with regard to secularism in Turkey, cf. T.J. Gunn, The "Principle of Secularism" and the European Court of Human Rights: A Shell Game, [in:] J. Temperman, T.J. Gunn, M.D. Evans (eds.), The European Court of Human Rights and the Freedom of Religion or Belief. The 25 Years since Kokkinakis, Leiden-Boston 2019, pp. 501-507.

16 Kokkinakis v. Greece, no. 14307/88, ECHR 1993. 
Court found that the prohibition of proselytism resulting in punishment of Minos Kokkinakis (a Jehovah's Witness punished for allegedly trying to convert another person after consensually entering their home) violated freedom of religion. This may be not the most fortunate case to begin with, due to the fact that with regards to secularism itself said case is rather uninteresting, as the words "secular" or "secularism" do not appear even once in the judgment. However, this lack of consideration of secularism is important in comparison to other judgments.

Firstly, the judgment lacks a section on comparative law. Such sections often appear in other judgments. These sections allow to present relevant legal regulations enacted by other contracting states of the Convention. Had the Court decided to carry out such an analysis, it would have been able to reflect that, for instance, even states with secular traditions do not impose such strict regulations regarding the issue of proselytism. ${ }^{17}$ Secondly, even the dissenting opinion that could be called secularist in spirit do not refer to secularism. Judge Valticos points out that "As with all freedoms, everyone's freedom of religion must end where another person's begins. Freedom "either alone or in community with others and in public or private, to manifest [one's] religion", certainly means freedom to practise and manifest it, but not to attempt persistently to combat and alter the religion of others, to influence minds by active and often unreasonable propaganda. It is designed to ensure religious peace and tolerance, not to permit religious clashes and even wars, particularly at a time when many sects manage to entice simple, naïve souls by doubtful means." 18 These remarks appear to be in line with understanding freedom of religion as one of the principles of secularism. This passage may also serve as an argument for a remark made earlier - perhaps the achievement of freedom of religion is nowadays so obvious that its secularist roots are not readily apparent. All things considered, Kokkinakis v. Greece is a unique case which on one hand concerns freedom of religion, but on the other hand does not mention secularism.

Another landmark case concerning freedom of religion is Leyla Şahin v. Turkey. This case is rather different than Kokkinakis v. Greece with regard to secularism. The applicant, Leyla Şahin, was a medical student at the University of Istanbul. The University issued a ban on religious attire. Şahin was denied access to an exam due to the fact that she was wearing a headscarf. Following that incident she was also refused when she tried to enroll in a course or to participate in lectures or

17 It has to be clarified that the prohibition of proselytism in Greece was a result of the dominant position of the Greek Orthodox Church (actually enshrined in Greek Constitution) and not of any secular tendency.

18 Kokkinakis v. Greece, no. 14307/88, Dissenting opinion of Judge Valticos, ECHR 1993. 
take exams. Eventually, she was suspended (she was later subject to amnesty). In her application to the European Court of Human Rights she argued that the authorities violated Articles 8, 9, 10 and 14 of the European Convention on Human Rights and Article 2 of Protocol No. 1. The Chamber found that there was no violation of the Convention. The case was referred to the Grand Chamber, which also found no violation.

Both of the judgments share almost identical sections with regard to relevant law and practice. These sections constitute a study in Turkey's secularism. It has to be emphasized that secularism is a leading theme, while one would be perhaps inclined to expect an inquiry into regulations concerning directly freedom of religion and other relevant principles. Accordingly, one of subsections is entitled "Religious dress and the principle of secularism." ${ }^{19}$ Great attention is paid to a verdict in which the Turkish Constitutional Court found a provision that allowed for religious headscarves to be worn at universities to be unconstitutional. It is worth noting that the judgment of the Grand Chamber has been actually expanded in this part in comparison to the Chamber's judgment. It could be argued that this expansion (which also allows for a more comprehensive presentation of the relevant provisions of the Constitution of the Republic of Turkey) prepares a field for a judgment favorable to the Turkish State. The Grand Chamber quotes directly from said judgment of the Constitutional Court: "Secularism is the civil organiser of political, social and cultural life, based on national sovereignty, democracy, freedom and science. Secularism is the principle which offers the individual the possibility to affirm his or her own personality through freedom of thought and which, by the distinction it makes between politics and religious beliefs, renders freedom of conscience and religion effective." ${ }^{20}$

The judgments in Leyla Şahin v. Turkey have extensive comparative law sections. A presentation of the relevant legal regulations in France begin in the following way: "In France, where secularism is regarded as one of the cornerstones of republican values (...)." ${ }^{21}$ But this remark, however valuable in pointing out that the Court takes note of secularism, may be just made in passing, not representative for the whole judgment. This is not the case. Grand Chamber's ruling on Leyla Şahin v. Turkey proceeds to be largely a study of Turkey's secularism.

The Court's assessment in this case is based on the doctrine of the margin of appreciation, i.e. due to the lack of European consensus on the matter at hand, special importance is given to national traditions of a particular contracting state.

19 Leyla Şahin v. Turkey, no. 44774/98, § 30-35, ECHR 2004.

20 Ibidem, § 39, ECHR 2005.

21 Ibidem, $\S 56$. 
This allows for the contracting state to implement the Convention on a particular matter in its own way (which may not be acceptable in the case of other states). That is the reason behind the deliberations on secularism in Turkey - its secularist tradition provides a justification for the ruling. The Great Chamber refers extensively to opinions of the Constitutional Court: "In its judgment of 7 March 1989, the Constitutional Court stated that secularism, as the guarantor of democratic values, was the meeting point of liberty and equality. The principle prevented the State from manifesting a preference for a particular religion or belief; it thereby guided the State in its role of impartial arbiter, and necessarily entailed freedom of religion and conscience. It also served to protect the individual not only against arbitrary interference by the State but from external pressure from extremist movements. The Constitutional Court added that freedom to manifest one's religion could be restricted in order to defend those values and principles." 22

It could be argued that in one passage the Court, perhaps unknowingly, is very close to admitting that the European Convention on Human Rights is in fact secularist in spirit. "As the Chamber rightly stated (...), the Court considers this notion of secularism to be consistent with the values underpinning the Convention. It finds that upholding that principle, which is undoubtedly one of the fundamental principles of the Turkish State which are in harmony with the rule of law and respect for human rights, may be considered necessary to protect the democratic system in Turkey. An attitude which fails to respect that principle will not necessarily be accepted as being covered by the freedom to manifest one's religion and will not enjoy the protection of Article 9 of the Convention (...)." 23

If the terminological proposition presented previously in this paper are accepted, one could even argue that in the judgment on Leyla Şahin v. Turkey the Court actually abandons the consideration of freedom of religion and makes an argument for a particular form of separation. ${ }^{24}$ This observation seems to be shared by Judge Tulkens, who writes in her dissenting opinion: "The Court's jurisdiction is, of course, subsidiary and its role is not to impose uniform solutions, especially "with regard to establishment of the delicate relations between the Churches and the State" (...) even if, in certain other judgments concerning conflicts between religious communities, the Court has not always shown the same judicial restraint (...). I therefore entirely agree with the view that the Court must seek to reconcile universality and diversity and that it is not its role to express an opinion on any

\footnotetext{
22 Ibidem, $\S 113$.

23 Ibidem, $\S 114$.

24 Similar point is raised in T. Hoopes, The Leyla Sahin v. Turkey Case Before the European Court of Human Rights, „Chinese Journal of International Law” 2006, 5(3), pp. 721-722.
} 
religious model whatsoever" 25 and then proceeds to object to applying the doctrine of margin of appreciation in this particular case. Furthermore, Judge Tulkens points out that "relying exclusively on the reasons cited by the national authorities and courts, the majority put forward, in general and abstract terms, two main arguments: secularism and equality." ${ }^{26}$ She then scrutinizes these two arguments with regard to the ECHR case-law and the actual situation of the applicant. This analysis is in stark contrast to the judgment, which indeed seems to settle for seconding the authorities: "Having regard to the above background, it is the principle of secularism, as elucidated by the Constitutional Court (...) which is the paramount consideration underlying the ban on the wearing of religious symbols in universities. In such a context, where the values of pluralism, respect for the rights of others and, in particular, equality before the law of men and women are being taught and applied in practice, it is understandable that the relevant authorities should wish to preserve the secular nature of the institution concerned and so consider it contrary to such values to allow religious attire, including, as in the present case, the Islamic headscarf, to be worn."27

Perhaps the most famous case not only with regard to freedom of religion, but also the most famous case in general adjudicated by the European Court of Human Rights to date, is Lautsi v. Italy, often dubbed "the Italian crucifix case". In this case the applicant argued that the presence of a crucifix in a classroom in the school which her children attended constitutes a violation of freedom of religion and belief (Art. 9 of the Convention), and also a violation of the right to education and teaching in conformity with her religious and philosophical convictions (Art. 2 of Protocol No. 1). One of the points that the applicant raised was that "The provisions concerned [with the presence of a crucifix in classrooms] were the legacy of a religious conception of the State which in present-day Italy was now in conflict with the State's duty of secularism, and infringed the rights protected by the Convention." ${ }^{28}$ In its judgment, the Chamber found that there has been a violation of Article 2 of Protocol No. 1 taken together with Article 9 of the Convention. However, in its assessment, the Chamber did not directly address the issue of secularism, despite the fact that it was raised not only by the applicant, but also by the Italian government, which argued that the presence of a cross "was perfectly compatible with secularism and accessible to non-Christians and non-believers (...)",29 and that

25 Leyla Şahin v. Turkey [GC], no. 44774/98, Dissenting opinion of Judge Tulkens, § 2, ECHR 2005.

26 Ibidem, $\S 4$.

27 Leyla Şahin v. Turkey [GC], no. 44774/98, § 116, ECHR 2005.

28 Lautsi v. Italy, no. 30814/06, § 30, ECHR 2009.

29 Ibidem, § 35. 
"there was no European consensus on the way to interpret the concept of secularism in practice, so that States had a wider margin of appreciation in the matter. More precisely, although there was a European consensus concerning the principle of the secular nature of the State, there was no such consensus about its practical implications or the way to bring it about." ${ }^{30}$ The case in question may be interpreted in the way proposed in present paper. The government attempts to present the case as if it concerned secularism (i.e. the issue of separation), the degree of which is not regulated by the Convention, or a least in the Court's practice is subject to the margin of appreciation. However, the Chamber focused on the alleged violation of freedom of religion.

The verdict of the Chamber was later overturned by the Grand Chamber. In its assessment, the Grand Chamber escaped from an analysis of the principle of secularism with regard to Italian law: "[It is not] for the Court to rule on the compatibility of the presence of crucifixes in State-school classrooms with the principle of secularism as enshrined in Italian law." ${ }^{\prime 31}$ Firstly, a stark contrast between final judgment in this case and the case of Leyla Şahin v. Turkey is noticeable. While Leyla Şahin v. Turkey contained an extensive and detailed analysis of relevant domestic regulations with regard to secularism, the Grand Chamber's judgment in Lautsi v. Italy directly refuses to analyze relevant domestic Italian law. Instead, the judgment mostly revolves around the alleged violation of Art. 2 of Protocol No. 1 (right to education). The Court decided that no separate issue arose under Article 9 (freedom of thought, conscience and religion) of the Convention. However, even in this context the issue of separation seems to be inescapable. Eventually, the Court - similarly to Leyla Şahin v. Turkey - pushes the issue of a supposed violation into the sphere of separation: "The fact remains that the Contracting States enjoy a margin of appreciation in their efforts to reconcile exercise of the functions they assume in relation to education and teaching with respect for the right of parents to ensure such education and teaching in conformity with their own religious and philosophical convictions (...). That applies to organisation of the school environment and to the setting and planning of the curriculum (...). The Court therefore has a duty in principle to respect the Contracting States' decisions in these matters, including the place they accord to religion, provided that those decisions do not lead to a form of indoctrination (...). The Court concludes in the present case that the decision whether crucifixes should be present in State-

\footnotetext{
$30 \quad$ Ibidem, $\S 41$.

31 Lautsi v. Italy [GC], no. 30814/06, § 57, ECHR 2011.
} 
-school classrooms is, in principle, a matter falling within the margin of appreciation of the respondent State." 32

It can be argued that when a case is put in terms of presence of religion in public life (i.e. in terms of separation), it is easy for the Court to refer to the margin of appreciation. ${ }^{33}$ However, if an alleged violation of principles is considered directly, such an operation is problematic. It is worth noting that while perhaps escapist to an extent, the judgments cannot be considered to be pro- or anti-religious.

\section{Secularism as a personal conviction}

It has been pointed out that in the judgments of the European Court of Human Rights secularism is understood as a principle followed by a given state. However, in one passage of the Grand Chamber judgment on Lautsi v. Italy, secularism is understood as a personal conviction or belief: "[T]he Court emphasizes that the supporters of secularism are able to lay claim to views attaining the "level of cogency, seriousness, cohesion and importance" required for them to be considered "convictions" within the meaning of Articles 9 of the Convention and 2 of Protocol No. 1 (see Campbell and Cosans v. the United Kingdom (...)). More precisely, their views must be regarded as "philosophical convictions", within the meaning of the second sentence of Article 2 of Protocol No. 1, given that they are worthy of "respect 'in a democratic society'", are not incompatible with human dignity and do not conflict with the fundamental right of the child to education (ibidem)." ${ }^{\prime 4}$

Not much can be said about this observation. The wording of the passage presented raises doubts whether the Court actually considers secularism to be protected by Article 9, since it immediately narrows the scope of the issue to the second sentence of Article 2 of Protocol No. 1. The fact that in this particular case the supporter of secularism actually lost adds to the confusion. The case the Court refers to, Campbell and Cosans v. the United Kingdom, ${ }^{35}$ concerned the use of corporal punishment as a disciplinary measure in schools in Scotland. The "philosophical conviction" debated in that case was the parents' opposition to the use of corporal punishment; the Court found that there has been a violation of Article 2 of Protocol No. 1. A lack of a more detailed comparison of the two cases in the

\footnotetext{
32 Ibidem, § 69-70.

33 Cf. Z.R. Calo, Pluralism, Secularism, and the European Court of Human Rights, "Journal of Law and Religion" 2010-2011, 26(1), p. 265.

34 Lautsi v. Italy [GC], no. 30814/06, § 58, ECHR 2011.

35 Campbell and Cosans v. the United Kingdom, no. 7511/76; 7743/76, ECHR 1982.
} 
judgment begs the question what was the Court's rationale for finding a violation in Campbell and Cosans and not finding it in Lautsi.

It is worth nothing that Marek Piechowiak, in his paper regarding the Lautsi case, while discussing negative religious freedom (which, in his opinion, entails the principle of secularism ${ }^{36}$ ), states that accepting the principle of secularism as understood by the Chamber could lead to a variety of consequences that would be difficult to accept, ${ }^{37}$ including destruction of tolerance. ${ }^{38}$ As regards secularism as a philosophical conviction, Piechowiak considers the Grand Chamber's adjudication to be problematic, as he finds it difficult to accept that secularist views "are worthy of "respect 'in a democratic society"', are not incompatible with human dignity." ${ }^{\prime 39}$ In his opinion, secularism is in fact a political belief, and as such is therefore enshrined in Article 10 of the Convention. ${ }^{40}$

\section{Conclusion}

In the first part of the article, a certain concept of secularism was accepted as a working definition. This explanation of secularism as a set of three principles: separation of church and state, freedom of religion, and equality (equated with prohibition of discrimination) proved to be fruitful in the analysis of three of the landmark cases of the European Court of Human Rights with regard to the issue of freedom of religion. It has been pointed out that the issue of what has been defined as separation (as a constitutive principle of secularism) is not for the Court to adjudicate on (as, contrary to freedom of religion and prohibition of discrimination, it is not enshrined in the Convention), and though not referenced verbatim, it was taken note of in the judgements. It has been observed that when the mention of secularism was absent from the judgment, the Court focused on the question of alleged violation of freedom of religion (Kokkinakis v. Greece). However, the appearance of the issue of secularism allowed the court to refer to the doctrine of the margin of appreciation, and consequently to rule in favor of the contracting state. In Leyla Şahin v. Turkey an extensive study of secularism in Turkey was conducted, and in effect provided justification for a certain ruling; a dissenting

\footnotetext{
36 M. Piechowiak, Negatywna wolność religijna i przekonania sekularystyczne w świetle sprawy Lautsi przeciwko Włochom, „Przegląd Sejmowy” 2011, 5(106), p. 53.

37 Ibidem, pp. 53-56.

38 Ibidem, p. 55.

39 Ibidem, p. 63.

$40 \quad$ Ibidem, p. 65.
} 
opinion, perhaps in line in with what is argued in this article, pointed out that the focus on secularism drew the Court's attention away from the issue of an alleged violation. In Lautsi v. Italy, the Chamber's judgment concentrated on the violation despite the state's attempt to shift the focus to the sphere of separation. However, the Grand Chamber's judgment in Lautsi v. Italy, despite claiming to discard the issue of secularism in Italy whatsoever, actually referred to separation, therefore allowing itself to shift the problem from the violation of freedom of belief to a sphere subject to the doctrine of the margin of appreciation.

The Court's understanding of secularism as a personal belief remains enigmatic and, together with other references to secularism in the Court's judgments, necessitates further study.

\section{Bibliography}

Calo Z.R., Pluralism, Secularism, and the European Court of Human Rights, "Journal of Law and Religion" 2010-2011, 26(1), pp. 261-280.

Eberle C., Cuneo T., Religion and Political Theory, [in:] E.N. Zalta (ed.), The Stanford Encyclopedia of Philosophy, Stanford 2017.

Gunn T.J., The "Principle of Secularism" and the European Court of Human Rights: A Shell Game, [in:] J. Temperman, T.J. Gunn, M.D. Evans (eds.), The European Court of Human Rights and the Freedom of Religion or Belief. The 25 Years since Kokkinakis, Leiden-Boston 2019, pp. 465-572.

Hoopes T., The Leyla Sahin v. Turkey Case Before the European Court of Human Rights, "Chinese Journal of International Law" 2006, 5(3), pp. 719-722.

Kurtul A.K., Secularism and the European Court of Human Rights, https://www.academia. edu/30080790/SECULARISM_AND_THE_EUROPEAN_COURT_OF_HUMAN_ RIGHTS_AN_UNCANNY_RELATIONSHIP.

Piechowiak M., Negatywna wolność religijna i przekonania sekularystyczne w świetle sprawy Lautsi przeciwko Włochom, „Przegląd Sejmowy” 2011, 5(106), pp. 37-68.

\section{Legal acts}

Convention for the Protection of Human Rights and Fundamental Freedoms (European Convention on Human Rights, as amended).

\section{ECHR judgements}

Campbell and Cosans v. the United Kingdom, no. 7511/76; 7743/76, ECHR 1982.

Kokkinakis v. Greece, no. 14307/88, ECHR 1993.

Lautsi v. Italy, no. 30814/06, ECHR 2009.

Lautsi v. Italy [GC], no. 30814/06, ECHR 2011. 
Leyla Şahin v. Turkey, no. 44774/98, ECHR 2004.

Leyla Şahin v. Turkey [GC], no. 44774/98, ECHR 2005.

\section{Online sources}

https://www.lexico.com/en/definition/secularism

https://www.merriam-webster.com/dictionary/secularism

https://www.secularism.org.uk/about.html

https://www.secularism.org.uk/what-is-secularism.html

https://sjp.pl/sekularyzm 